\title{
Effect of the Simultaneous Variation in Blade Root Chord Length and Blade Taper on Maneuvering Manned Helicopter Control Effort
}

\author{
Firat $\mathrm{Sal}^{1 *}$ \\ ${ }^{1}$ Kelkit College of Aydin Dogan, Gumushane University, Kelkit, Turkey, (ORCID: 0000-0003-2412-4131)
}

(First received 30 December 2018 and in final form 20 March 2019)

(DOI: 10.31590/ejosat.505378)

REFERENCE: Sal, F. (2019). Effect of the Simultaneous Variation in Blade Root Chord Length and Blade Taper on Maneuvering Manned Helicopter Control Effort. European Journal of Science and Technology (15), 475-482.

\begin{abstract}
In this article, the influence of simultaneous variation in blade root chord length and blade taper on the flight control effort of maneuvering helicopter is researched. For this intention, helicopter models which are complex, control-oriented, physics-based models and capturing the main-physics and essential-dynamics are benefited. The influence of simultaneous variation in the blade root chord length and blade taper (i.e., in both chordwise and lengthwise directions dependently) on the control effort of a maneuvering manned helicopter and also on the closed-loop responses are worked. Comparisons in terms of the control effort and peak-values with and without variations in the blade root chord and blade taper changes are followed. For helicopter control variance-constrained controllers (i.e. output variance-constrained controllers) are useful. Shortly, in also maneuvering flight conditions effects and benefits of simultaneous variation in blade root chord length and blade taper on the flight control effort is tried to be proved.
\end{abstract}

Keywords: Maneuvers, Helicopters, Blade Root Chord Length, Blade Taper, Control Effort Saving, Flight Control System, ClosedLoop Response.

\section{Pale Kök Veter Uzunluğu ve Pale Daralmasının Eş Zamanlı Değişiminin Manevra Yapan İnsanlı Helikopterin Kontrol Çabası Üzerindeki Etkisi}

Öz

Bu çalışmada, pale kök veter uzunluğu ve pale daralmasının eş zamanlı değişiminin manevra yapan insanlı helikopterin kontrol çabası üzerindeki etkisi araştırılmıştır. Bu maksatla karmaşık, kontrol amaçlı, fizik temelli, temel fizik ve gerekli dinamikleri içeren helikopter modellerinden faydalanılmıştır. Pale kök veter uzunluğu ve pale daralmasının (hem veter açıklığı hem de uzunluk doğrultularında aynı şekilde) eş zamanlı değişiminin manevra yapan insanlı helikopterin kontrol çabası ve ayrıca kapalı çevrim cevaplarındaki etkileri çalışılmıştır. Kontrol çabası ve pik değerler için pale kök veter uzunluğu ve pale daralmasının gerçekleştiği ve gerçekleşmediği durumlarda kıyaslamalar yapılmıştır. Kısacası pale kök veter uzunluğu ve pale daralmasının eş zamanlı değişiminin manevralı uçuş koşullarında dahi etkileri ve faydaları ispatlanmaya çalışılmıştır.

Anahtar Kelimeler: Manevralar, Helikopterler, Pale Kök Veter Uzunluğu, Kontrol Çabası Kazancı, Uçuş Kontrol Sistemi, KapalıÇevrim Cevabı.

\footnotetext{
*Sorumlu Yazar: Kelkit College of Aydin Dogan, Gumushane University, Kelkit, Turkey, ORCID: 0000-0003-2412-4131, drfiratsal@gmail.com
} 


\section{Introduction}

Methods for minimizing the control effort of a flight control system (FCS) of a helicopter were frequently and commonly examined in the literature(Bluman \& Gandhi, 2011; D Fusato \& Celi, 2006; Dario Fusato, Guglieri, \& Celi, 2001; Luo, Liu, Yang, \& Chang, 2003; Tugrul Oktay \& Sal, 2015; T Oktay \& Şal, 2015; Tugrul Oktay \& Sultan, 2013a, 2013b, 2013c, 2014). Limited number of studies studies on the helicopter blade root chord length and blade taper have been done recently for different reasons(Kambampati, Ganguli, \& Mani, 2013; Tugrul Oktay \& Sal, 2017; Özdemir \& Kaya, 2006; Ozgumus \& Kaya, 2007; Vu \& Lee, 2015). For instance, in (Özdemir \& Kaya, 2006), flapwise bending vibration analysis of a rotating, tapered cantilever Bernoulli-Euler beam (e.g., helicopter blade) was followed via benefiting the differential transform method. The effect of blade taper on natural frequencies was also worked. It was obtained that the natural frequencies of a rotating, tapered cantilever Bernoulli-Euler beam can be determined with high correctness via benefitting the differential transform method. In addition to the previous study, the effect of blade taper on the control effort of the flight control system of a helicopter was also studied in (Tugrul Oktay \& Sal, 2017). In that article, blade root chord, blade taper and the gains of the output variance-constrained controller (OVC)-based helicopter FCS were the optimization parameters during straight level flight.It was obtained in this article that when blade taper is required to applied due to the performance reasons, blade root chord has to be used in order not to increase control effort.

Numerous control approaches for the helicopter FCS have been found recently(Dalamagkidis, Valavanis, \& Piegl, 2011; Hsieh, Skelton, \& Damra, 1989; Li, Liu, \& Song, 2011; Skelton, 1987; Skelton, Iwasaki, \& Grigoriadis, 1998). The use of variance-constrained controllers is one these approaches(Skelton, 1987). These kinds of controllers have many advantages with respect to the other existing common controllers. One of these advantages is that variance-constrained controllers are enhanced LQG controllers and they include Kalman filters for state estimators. In this article, a specific variance-constrained controller, the OVC, is used for helicopter FCS during maneuvering flight.

In this article, the simultaneous effect of the helicopter blade taper and blade root chord length on the control effort of the FCS of a helicopter during maneuvering flight is for the first time examined with OVCs. Furthermore, comparisons in terms of the peak values of closed-loop responses with and without variations in the blade root chord and blade taper changes are followed for the first time in the literature.

\section{Our Helicopter models}

In this article, the helicopter models summarized in (Tugrul Oktay \& Sal, 2015; Tugrul Oktay \& Sal, 2017; T Oktay \& Şal, 2015) are benefited. These models are concisely summarized next. They captures the physics principles leading to dynamic models consisting of a finite set of ordinary differential equations. These models includes the fuselage, empennage, landing gear, fully articulated main rotor (i.e., with four blades), main-rotor downwash, and tail rotor. As a result, these models are accurately complex with a total of 29 equations: 9 fuselage equations, 16 blade flapping and lead-lagging equations, 3 static main-rotor downwash equations, and an additional flight-path angle algebraic equation. In Figs. 1 and 2 the blade taper and balde root chord are illustrated. Their effect on control effort and closed loop responses will be examined in this article next.

a.
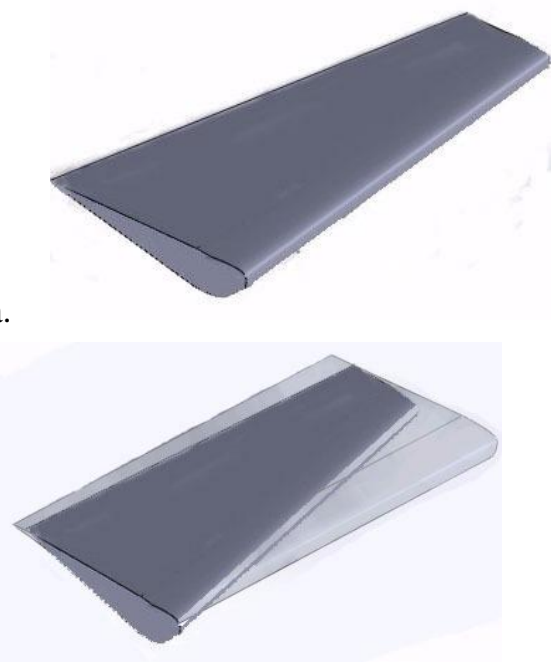

Fig. 1. Tapered Helicopter Blade a. Tapered Blade b. Both Tapered and Untapered Blades (Taken from (Tugrul Oktay \& Sal, 2017)) 


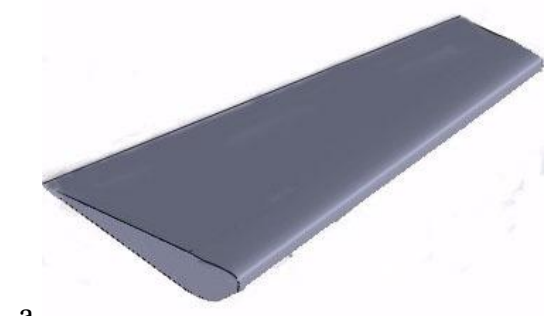

a.

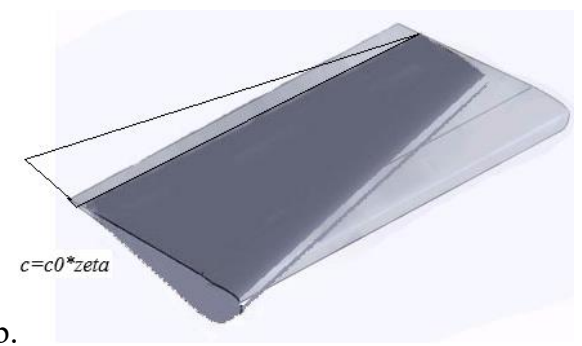

Fig. 2. Illustration of Variation in Blade Root Chord

a. Just Tapered Blade b. Both Taper and Blade Root Chord Variations Applied (Taken from (Tugrul Oktay \& Sal, 2017))

\section{Variance Constrained Control}

For a clear continuous linear time invariant (LTI), stabilizable and detectable plant (Dalamagkidis et al., 2011; Hsieh et al., 1989; Li et al., 2011; Skelton, 1987; Skelton et al., 1998)

$$
\dot{x}_{p}=A_{p} x_{p}+B_{p} u_{p}+w_{p}, y=C_{p} x_{p}, \mathrm{z}=M_{p} x_{p}+v
$$

and a positive definite input penalty matrix, $R>0$, find a full order dynamic controller

$\dot{x}_{c}=A_{c} x_{c}+F \mathrm{z}, u_{p}=G x_{c}$

to response the problem

$$
\min _{A_{c}, F, G} J=E_{\infty} u_{p}^{T} R u_{p}=\operatorname{tr}\left(R G X_{c_{j}} G^{T}\right)
$$

expose to variance constraints on the output/outputs

$$
E_{\infty} y_{i}^{2} \leq \sigma_{i}^{2}, \quad i=1, \ldots, n_{y}
$$

Here $y$ and $z$ describe outputs of interest and sensor measurements, respectively, $w_{p}$ and $v$ are zero-mean uncorrelated Gaussian white noises with intensities of $W$ and $V$, respectively, $F$ and $G$ are state estimator and controller gain matrices, respectively, $x_{c}$ is the controller state vector, $\sigma_{i}^{2}$ is the upper limit imposed on the $i$-th output variance, $n_{y}$ is the number of outputs, and additionally $E_{\infty} \square \lim _{t \rightarrow \infty} E$, and $E$ is the expectation operator. In final, $t r$ and ${ }^{T}$ represent matrix trace and matrix transpose operators, respectively. The quantity of $J$ usually called as flight control system energy or flight control system cost and it is calculated via benefitting also the state covariance matrix, $X_{c}$. After the algorithm(Hsieh et al., 1989; Skelton, 1987; Skelton et al., 1998) converges and the output penalty matrix $Q$ is determined, OVC parameters are

$A_{c}=A_{p}+B_{p} G-F M_{p}, F=X M_{p}^{T} V^{-1}, G=-R^{-1} B_{p}^{T} K$ 
Here, $X$ and $K$ are solutions of solutions of two algebraic Riccati equations given next:

$0=X A_{p}^{T}+A_{p} X-X M_{p}^{T} V^{-1} M_{p} X+W$

$0=K A_{p}+A_{p}^{T} K-K B_{p} R^{-1} B_{p}^{T} K+C_{p}^{T} Q C_{p}$

\section{Results}

In this article, the effect of combined change in blade root chord length and blade taper on the control effort of the FCS of a helicopter is examined. For this intention, complex, control-oriented, physics-based helicopter models (see (Tugrul Oktay \& Sal, 2015; Tugrul Oktay \& Sal, 2017; T Oktay \& Şal, 2015) for further information) are trimmed and linearized around hover helical turn, 40-knots helical turn and 80-knots helical turn maneuvering conditions are applied. OVCs are designed with output variance constraints on helicopter Euler angles of $10^{\wedge}(-4)$, while all four helicopter controls are used as inputs. The noise intensities are $\mathrm{W}=10^{\wedge}(-7)$ x I_ 25 and $\mathrm{V}=10^{\wedge}(-7)$ x I_4.

In Figs. 3, 4 and 5 for hover helical turn, 40 kts helical turn and 80 kts helical turn, control effort $(\mathrm{J})$ as functions of taper ratio $(\Omega)$ and root chord $(\varepsilon)$ is given. It can be seen from these figures that for any of maneuvering flight condition when taper ratio is applied, the control effort increases. On the other hand, if root chord is extended the control effort decreases. These results are similar with the results found for straight level flight as in (Tugrul Oktay \& Sal, 2017).

In Figs. 6 and 7 effect of simultaneous variations in blade root chord and blade taper on some states and controls for 40 kts helical turn is given. Three scenarios are considered. The first one is original blade. The second one is for the situation that the taper ratio and root chord are applied in borders (version I). The third one is for the situation that taper ratio is chosen at the border and the root chord constant is chosen in order to keep blade area constant (version II). It is found that when it is required to use taper due to the performance reasons, the length of the blade root chord must also be increased in order to not rise the control effort of the FCS of the helicopter.

\section{Conclusions and Recommendations}

In this study, the effect of combined variation in blade root chord length and blade taper on the flight control effort of maneuvering helicopter was investigated. For this purpose, helicopter models which are complex, control-oriented, physics-based models and capturing the main-physics and essential-dynamics are applied. For the helical turn maneuvering flight conditions it is found that when taper ratio is applied, the control effort increases. On the other hand, if root chord is extended the control effort decreases. Moreover, when it is required to use taper due to the performance reasons, the length of the blade root chord must also be increased in order not to rise the control effort of the flight control system of the helicopter for also maneuvering flight. Consequently, in also maneuvering flight conditions effects and benefits of simultaneous variation in blade root chord length and blade taper on the flight control effort were proved in this study.

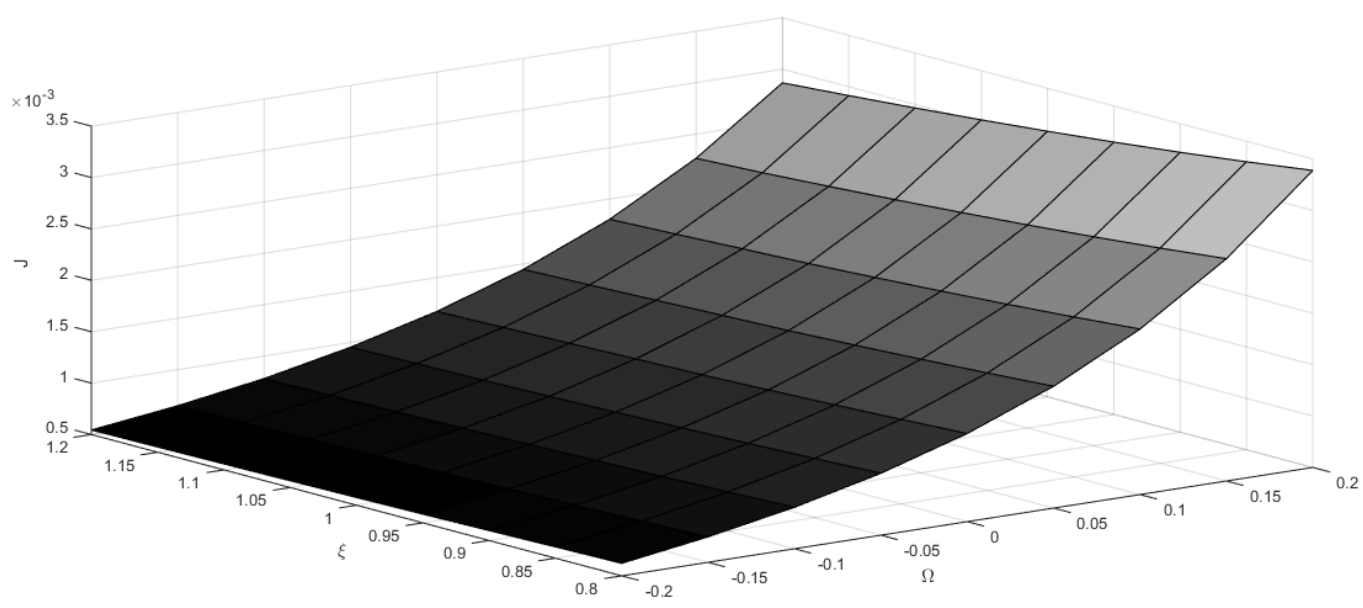


European Journal of Science and Technology

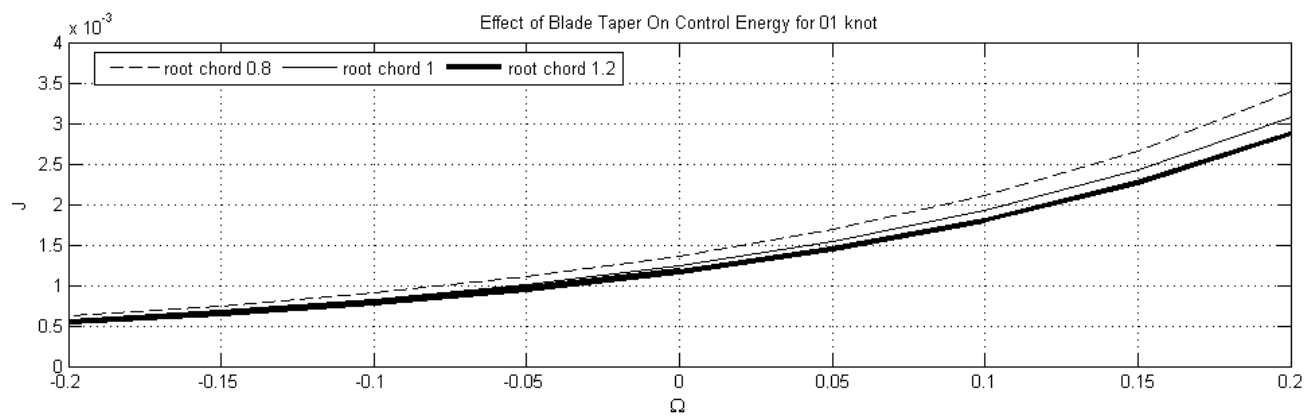

Fig. 3. Hover Helical Turn Energy Results
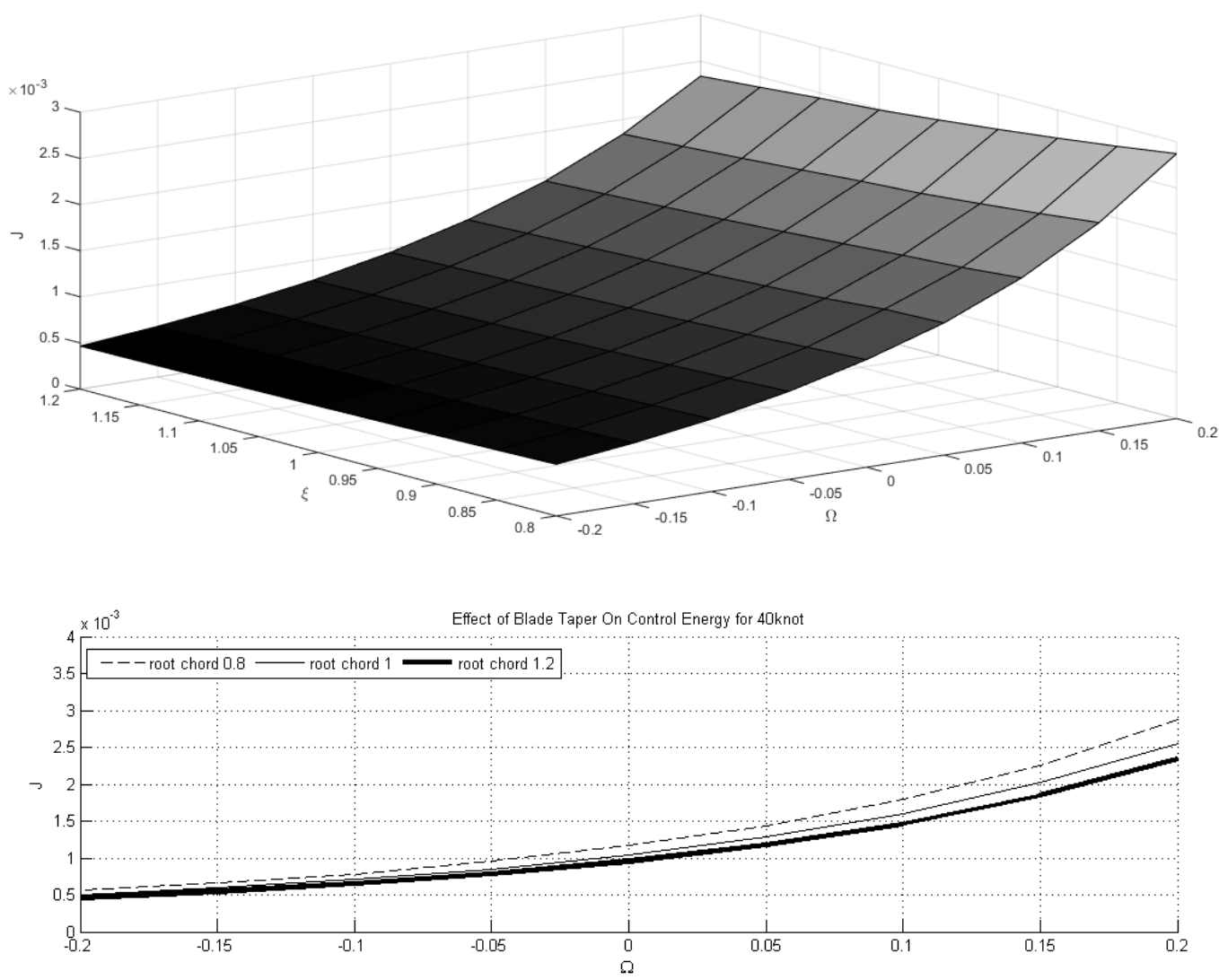

Fig. 4. 40 kts Helical Turn Energy Results

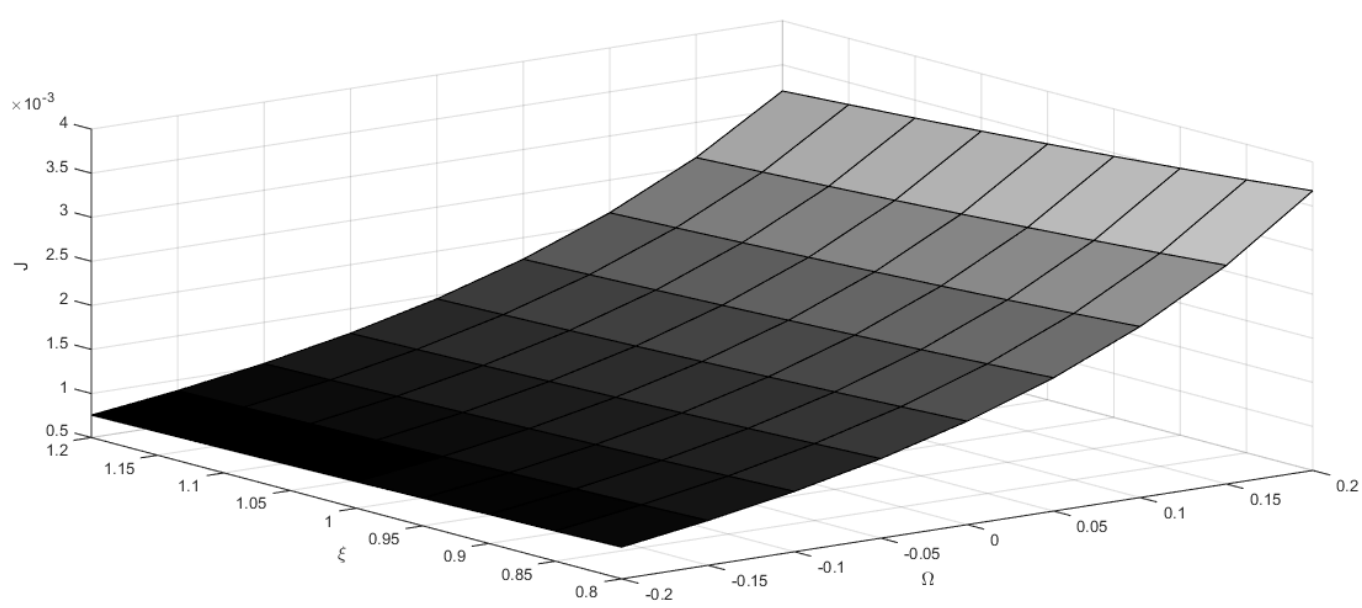


Avrupa Bilim ve Teknoloji Dergisi

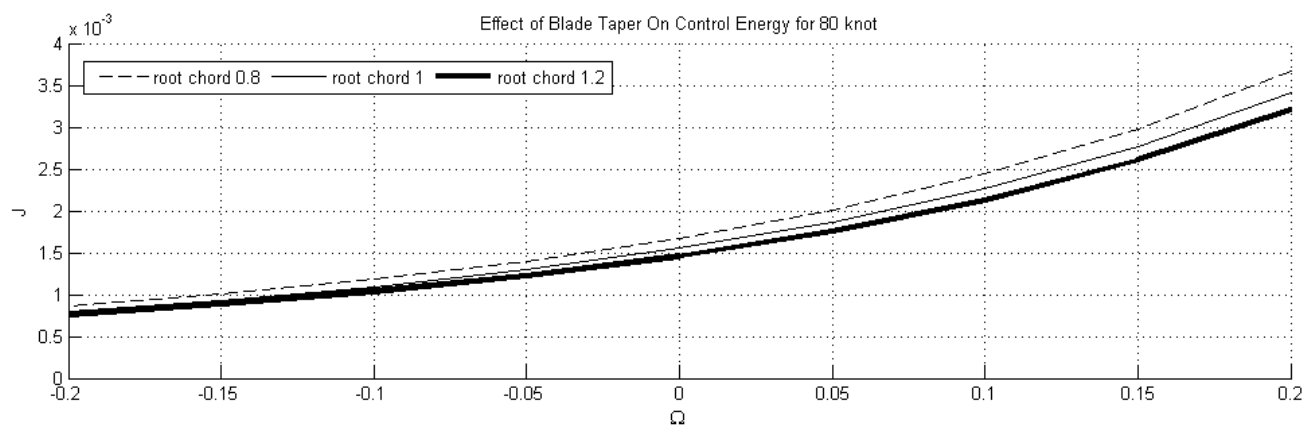

Fig. 5. 80 kts Helical Turn Energy Results
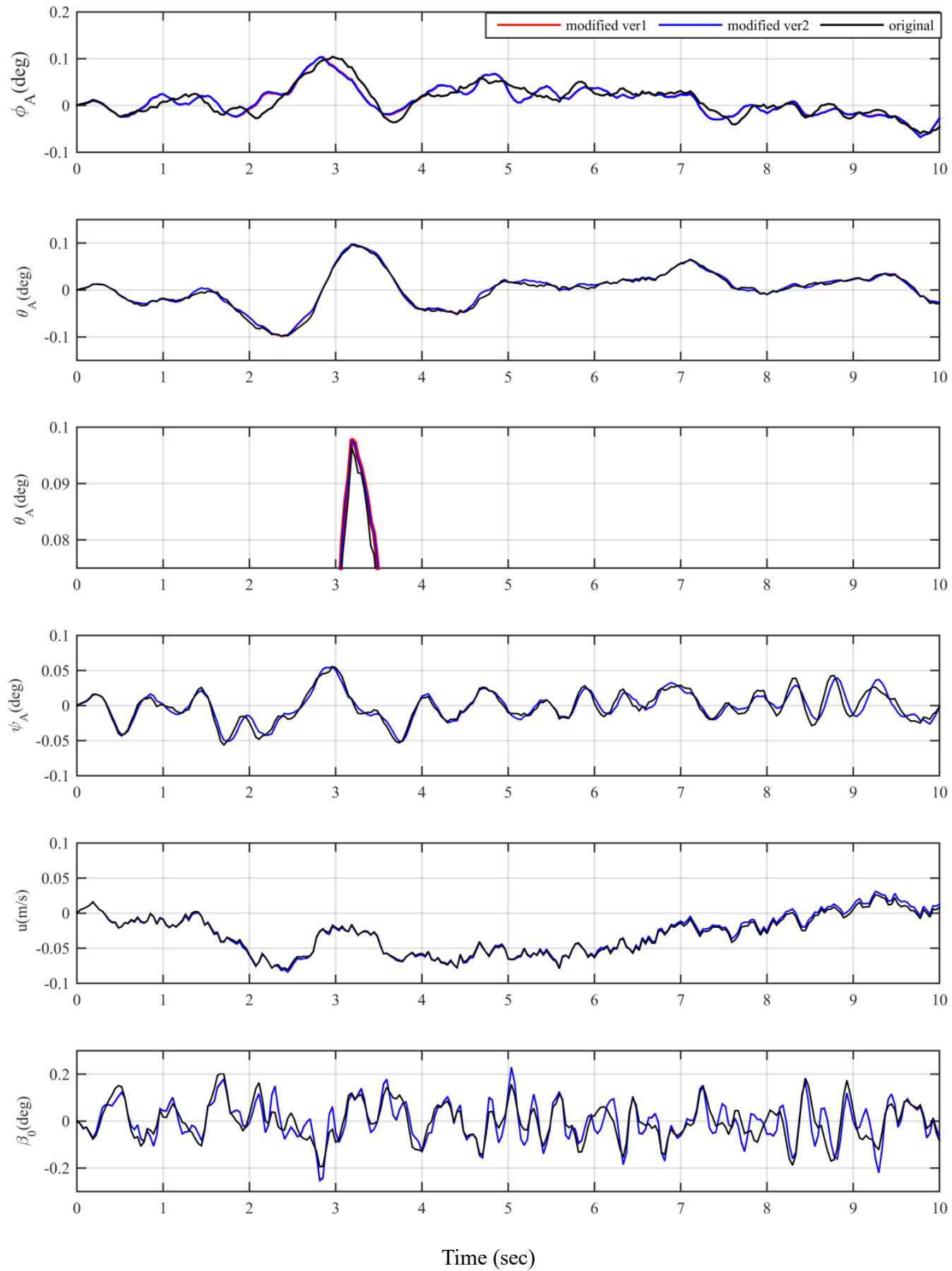
Fig. 6. Effect of Simultaneous Variations in Blade Root Chord and Blade Taper on some States for Helical Turn (40-knots, 0.1, 0.1)
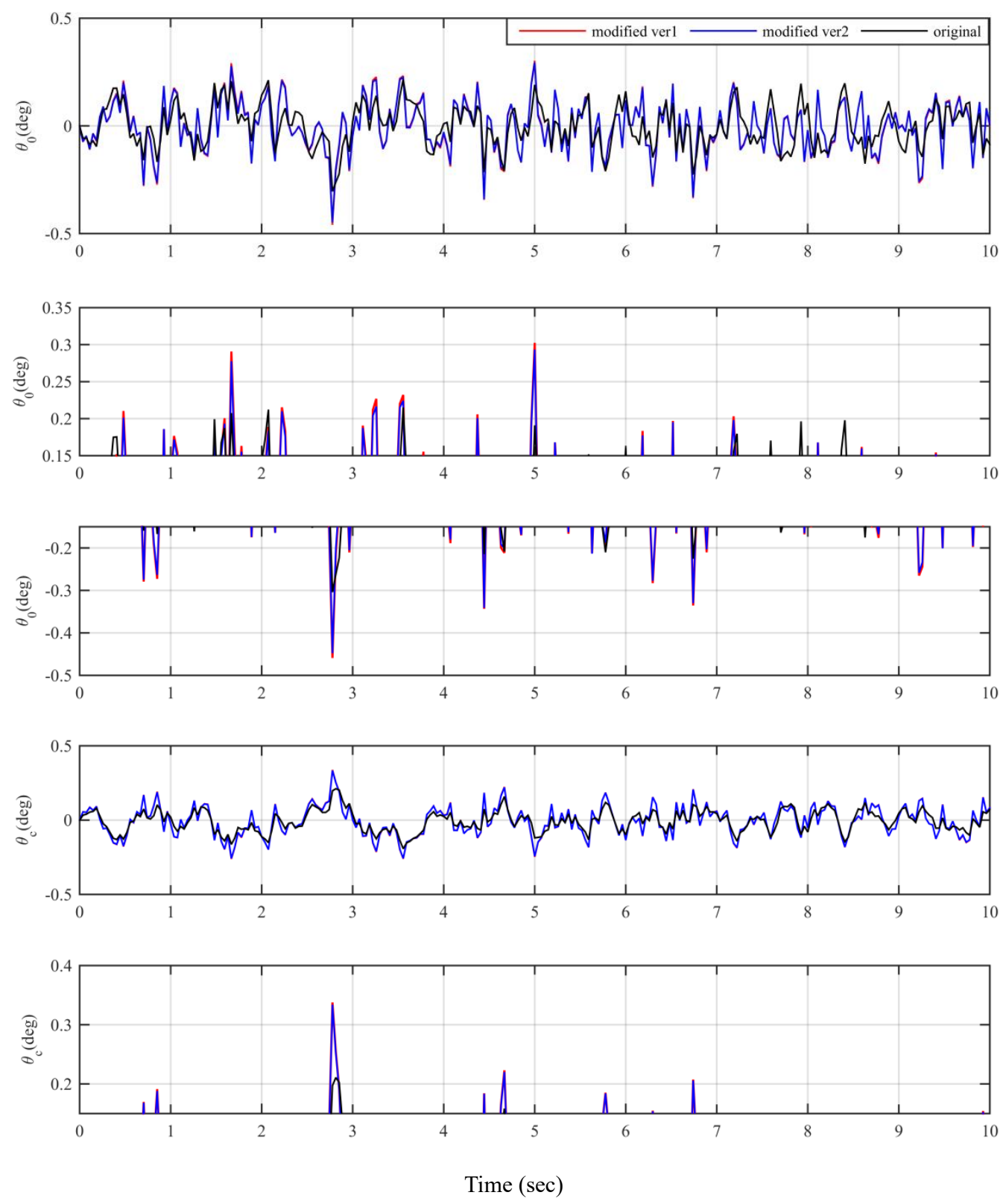

Fig. 7. Effect of Simultaneous Variations in Blade Root Chord and Blade Taper on some Controls for Helical Turn (40-knots, 0.1, 0.1) 


\section{References}

Bluman, J. E., \& Gandhi, F. S. (2011). Reducing trailing edge flap deflection requirements in primary control with a movable horizontal tail. Journal of the American Helicopter Society, 56(3), 1-12.

Dalamagkidis, K., Valavanis, K. P., \& Piegl, L. A. (2011). Nonlinear Model Predictive Control With Neural Network Optimization for Autonomous Autorotation of Small Unmanned Helicopters. IEEE Transactions on Control Systems Technology, 19(4), 818831. doi:10.1109/tcst.2010.2054092

Fusato, D., \& Celi, R. (2006). Multidisciplinary Design Optimization for Helicopter Aeromechanics and Handling Qualities. Journal of Aircraft, 43(1), 241-252.

Fusato, D., Guglieri, G., \& Celi, R. (2001). Flight dynamics of an articulated rotor helicopter with an external slung load. Journal of the American Helicopter Society, 46(1), 3-13.

Hsieh, C., Skelton, R., \& Damra, F. (1989). Minimum energy controllers with inequality constraints on output variances. Optimal Control Applications and Methods, 10(4), 347-366.

Kambampati, S., Ganguli, R., \& Mani, V. (2013). Non-rotating beams isospectral to a given rotating uniform beam. International Journal of Mechanical Sciences, 66, 12-21.

Li, Y.-b., Liu, W.-Z., \& Song, Q. (2011). Improved LQG control for small unmanned helicopter based on active model in uncertain environment. Paper presented at the Electronics, Communications and Control (ICECC), 2011 International Conference on.

Luo, C.-C., Liu, R.-F., Yang, C.-D., \& Chang, Y.-H. (2003). Helicopter Ho control design with robust flying quality. Aerospace Science and Technology, 7(2), 159-169.

Oktay, T., \& Sal, F. (2015). Helicopter Control Energy Reduction Using Moving Horizontal Tail. The Scientific World Journal, 2015.

Oktay, T., \& Sal, F. (2017). Effect of Combined Blade Root Chord Length and Blade Taper on Manned Helicopter Control Effort. Paper presented at the 6th International Research Conference on Science, Management and Engineering (IRCSME 2017), Dubai, UAE.

Oktay, T., \& Şal, F. (2015). Combined Passive And Active Helicopter Main Rotor Morphing For Helicopter Energy Save. Journal of the Brazilian Society of Mechanical Sciences and Engineering.

Oktay, T., \& Sultan, C. (2013a). Constrained predictive control of helicopters. Aircraft Engineering and Aerospace Technology, 85(1), $32-47$.

Oktay, T., \& Sultan, C. (2013b). Modeling and control of a helicopter slung-load system. Aerospace Science and Technology, 29(1), 206-222. doi:10.1016/j.ast.2013.03.005

Oktay, T., \& Sultan, C. (2013c). Simultaneous helicopter and control-system design. Journal of Aircraft, 50(3), 911-925.

Oktay, T., \& Sultan, C. (2014). Flight control energy saving via helicopter rotor active morphing. Journal of Aircraft, 51 (6), $1784-1804$.

Özdemir, Ö., \& Kaya, M. (2006). Flapwise bending vibration analysis of a rotating tapered cantilever Bernoulli-Euler beam by differential transform method. Journal of Sound and Vibration, 289(1), 413-420.

Ozgumus, O. O., \& Kaya, M. O. (2007). Energy expressions and free vibration analysis of a rotating double tapered Timoshenko beam featuring bending-torsion coupling. International journal of engineering science, 45(2), 562-586.

Skelton, R. E. (1987). Dynamic Systems Control: Linear Systems Analysis and Synthesis. John Wiley \& Sons: chapter 8.

Skelton, R. E., Iwasaki, T., \& Grigoriadis, K. (1998). A Unified Algebraic Approach to Linear Control Design (pp. chapter 4): Taylor \& Francis.

Vu, N. A., \& Lee, J. W. (2015). Aerodynamic design optimization of helicopter rotor blades including airfoil shape for forward flight. Aerospace Science and Technology, 42, 106-117. doi:10.1016/j.ast.2014.10.020 